\title{
UNDANG-UNDANG PANJI SELATEN DAN BERAJA N ITI TENTANG HUKUM ISLAM DI KESULTANAN KUTAI KERTANEGARA
}

\author{
Makmn Syari*
}

\begin{abstract}
A bstract: This paper disasses the prodem of inter-maniage between astomary lawand Istamiclawbyreferingtothelaus of Panii SdatenandBeraji Niti as a casein pint. These arethelaus of Kutai Ketanegara Sultanatein Kalimantan. The paper partiaularly asks to what extent does astomary lawin Kutai Ketanegara absombs Istamiclawandviceversa. We argue that this case is a pefeet example of not only theability of Idamto adapt to a local scenario but also the gerius of erity Musims in this particular region to understand the universal message of Idam That Idamis univessal mens that it is applicable in different settings and contexts. Wealso discuss the history of the two lavs, their dharadteistics and systems in order to preent a dear idea of how they connote to the Islamic values Further, throughthisstudy vetrytoshow thatinonewayorandher, theDutchodonizingpowerat the timewas avarethat tokeep theresistanceat bay, it hastoapply thepdicy of what VanDen Bergcalls reeeptioin complexu, that isreognizingandappdyingIsamiclawfor theMusins Keywords: Islamiclaw astomarylawreeetioin complexu
\end{abstract}

\section{Pendahuluan}

Kerajaan Kutai sering disebut dengan Kesultanan Kutai Kertanegara. Hal demikian disebabkan kepala pemerintahannya bergelar "sultan". ${ }^{1}$ Meskipun istilah kesultanan ini dikenal setelah kerajaan menerima dan dipengaruhi oleh ajaran Islam. Ada beberapa versi yang menerangkan tentang asal kata Kutai. Petama, Kutai berasal dari bahasa Hindu (Sansekerta) quitairyyang berarti hutan lebat atau hutan raya. Kemungkinan pemunculan kata ini karena tanah Kutai memiliki kekayaan alam yang melimpah ruah, di antaranya hutan. Versi keeua, berdasarkan monografi Kutai tahun 1968, kata Kutai berasal dari bahasa Cina yaitu Kho dan Thaiyang artinya Negara besar, argumentasi pendapat kedua ini setidaknya dilihat dari beberapa peninggalan benda-benda antik yang berasal dari negeri Cina dan hal ini terjalin karena hubungan dagang dan kontak budaya. ${ }^{2}$

Terlepas dari perbedaan versi asal penamaan Kutai, setidaknya penyebutan kata Kutai mengingatkan bahwa kesultanan Kutai adalah sebuah imperium yang telah menaklukkan

\footnotetext{
*Fakultas Syari'ah Sekolah Tinggi Agama Islam Negeri (STAIN) Samarinda.

${ }^{1}$ Sultan adalah gelar bagi seseorang yang memiliki kekuasaan tinggi dalam sebuah negara (pemerintahan). Gelar ini pertama kali dipakai dalam Islam pada zaman pemerintahan Abbasiyah (750-1258). Pada mulanya kekuasaan sultan terbatas dan berada di bawah khalifah, tetapi dalam perkembangan selanjutnya, kekuasaan sultan semakin besar, bahkan melebihi kekuasaan khalifah. Di zaman Abbasiyah, khalifah masih diakui dan dihormati oleh sultan, meskipun kekuasaan politik dan militer berada di tangan sultan. Khalifah hanya sekedar simbol, sementara jalannya pemerintahan ditentukan oleh sultan. D alam perkembangan berikutnya, sultan betul-betul berkuasa penuh atas daerah dan wilayahnya dan tidak berada di bahwa khalifah manapun. D alam kedudukan seperti ini sultan adalah raja sehingga istilah "sultan" digunakan sebagai gelar bagi seorang raja yang Muslim. G elar sultan pertama kali diberikan oleh khalifah Mu'tasim dari dinasti Abbsiyah (218 H/ 833 M - 228 H/ 842 M) kepada seorang panglima Turki bernama Asynas at-Turki. Sebagai sultan, Asynash at-Turki mempunyai kekuasaan besar, tetapi tetap berada di bawah dan tunduk kepada khalifah al-Mu'tasim.

${ }^{2}$ D epdikbud K altim, Wujud Arti dan Fungsi Puncak-puncak KdoudayaanLama danAsi di KalimantanTimr(Kaltim: Depdikbud, 1996), 9.
} 
kerajaan Hindu tertua di Indonesia pada tahun 1605, yaitu kerajaan Martadipura/ Martapura yang telah dikenal sebagai kerajaan Mulawarman.

Kesultanan Kutai bernama lengkap Kesultanan Kutai Karta Negara Ing Martadipura (Martapura), yang bermula dari dua kerajaan yang berbeda yang kemudian disatukan dalam bentuk penaklukan atas kerajaan Martadipura pada abad ke-17, yaitu semasa pemerintahan pangeran Sinum Panji Mendapa (1635-1650). Kerajaan Martadipura adalah kerajaan yang hidup sejak abad ke-4 dengan Kudungga sebagai rajanya yang pertama, terletak di pedalaman (hulu) aliran sungai Mahakam. Adapun kerajaan Kutai adalah kerajaan Melayu yang pada awal berdirinya merupakan koloni dari kerajaan Majapahit ${ }^{3}$ yang setelah menerima pengaruh ajaran Islam merubah nama menjadi kesultanan Kutai, dan pusat pemerintahan kesultanan Kutai ini di muara sungai Mahakam. ${ }^{4}$

Kerajaan Kutai, selain undang-undang Panji Selaten, juga memiliki sebuah kodifikasi hukum yang dikenal dengan undang-undang Beraja Niti. Semua persoalan yang muncul di masyarakat, baik masalah perdata maupun pidana diselesaikan dengan berpedoman pada undang-undang ini. Secara umum, undang-undang ini merujuk kepada ketentuan hukum Islam (fiqih) meski tidak sedikit pula yang digali dari adat setempat. Oleh karena itu, diperlukan sebuah penelitian yang cermat untuk mengungkap, hukum apa yang diberlakukan di kerajaan Beraja Niti.

\section{Karakteristik Politik Hukum Kesultanan}

Sejarah hukum kesultanan Kutai Kertanegara dimulai dengan diterbitkannya undangundang Panji Selaten berlaku sebagai konstitusi ${ }^{5}$ kerajaan Kutai yang terdiri dari 39 pasal dan undang-undang Beraja Nanti atau Beraja Niti dengan jumlah pasal sebanyak 14 pasal. Kedua perundangan ini diterbitkan semasa pemerintahan Pangeran Aji Sinum Panji Mandapa (1635-1650), dengan menggunakan aksara Arab Melayu. ${ }^{6}$

Ada beberapa faktor pendukung sehingga kerajaan mengambil kebijakan hukum dengan penerapan undang-undang Panji Selaten sebagai konstitusi kerajaan dan Beraja Niti sebagai undang-undang terapan. Petama, pengalaman runtuhnya dinasti Mulawarman yang memiliki sistem pemerintahan yang tidak terstruktur dengan baik. Kedua, pengaruh ajaran Islam yang secara prinsip menganggap politik pemerintahan adalah bagian yang tidak dapat dipisahkan dari persoalan agama. $\mathrm{D}$ an faktor kedua inilah yang lebih mewarnai sistem politik dan hukum kesultanan yang bershara'kan agama Islam. ${ }^{7}$

Dalam struktur kekuasaan elit kesultanan Kutai, pada prinsipnya telah terbangun sistem tata pemerintahan yang terstruktur sesuai dengan kebutuhan zamannya. Secara normatif hal demikian dapat dicermati dari berbagai pasal yang termuat dalam undangundang Panji Selaten, pasal 1, dinyatakan:

\footnotetext{
${ }^{3}$ Setwilda TK II Kutai, GdoraMahakamdalamCuplikanTulisan(Tenggarong: Setwilda, 1999$), 9$.

${ }^{4}$ Depdikbud Kaltim, Wujud, Arti, 71.

${ }^{5}$ Penulis lebih menekankan penggunaan istilah "konstitusi: pada UU Panji Selaten dalam tulisan ini, mengingat sifat dasar dari konstitusi sebagai norma antara (tusen nom genedlenom) sedangkan UU Beraja Niti lebih dimaknai dengan norma konkrit (conctenom) yang diterapkan di lembaga peradilan. Lihat Murjani, "Perkembangan Legislasi Hukum Islam dalam Pembentukan Sistem Hukum Nasional: Tinjauan Yuridis Politis", Tesis, Magister (S-2) Ilmu Hukum, UII Yogyakarta, 2002, 102.

${ }^{6}$ Murjani et.al, PekkenbencanPenerapan HukumISamdi KalimantanTimr(Samarinda: STAIN Samarinda, 2004), 31.

${ }^{7}$ Ibid., 33.
} 
Yangbemama kerajaan Kutai Kartanega IngMartapura, ialah yangBeaja, Bementri, Berarang Besar, Behulu balang Behukum dengan Adatrya, Beshara' Isam dangan Alim Ulamanya. Yang berpunggana, Berpetinggi, Berdusun, Bekkampung Bernegeri dan teluk rantaunya, Berpangima andkatan perbalanya.

D ari pasal 1 ini terlihat jelas bahwa struktur pemerintahan kerajaan Kutai telah tertata demikian rupa dan elit tertinggi yaitu raja sebagai struktur terendah yaitu bernegeri. Segala bentuk kebijakan penguasa tidak dapat ke luar kecuali ada kata mufakat (musyawarah) dan ini merupakan institusi hukum adat yang diadatkan dengan tetap berpedoman pada shara'. D alam pasal 9 dan pasal 39 dinyatakan:

Pasal 9: "Yangdiseat adat yang diadatkan, ialah adat hukumnegri. Ialah dibuat deh Majeis arangdarangyang anif lag bjjaksana dencan mfakatrya dan dibenarkan deh Raja. Lalu disedat adat yang dadatkan yang sudah mejadi sabda Pandita Ratu, jika siapa juapun menusaknya dimamakan ingkar dan mati hukumannya".

Pasal 39: "Adat besar Raja tiada bercerai. Seegla mfakat itu dan putus dalambalai dan dibenarkan deh Raja membenarkan kata mfakat ialah yang mejadi adat yang diadatkan Sebagai adat yang diadatkan mejjadi sabda Pandita Ratu yang tiada bisa benubah keeuali dengan mfakat. Barangsiapa yangmdanggar sabch Pandita Ratu artinya memotó lidah Raja, maka mati jua hukumya dengan tiada ampumannya. Adat yangdadatkan, ialah putusan dalam badai orangforang besar dan segla arang yang aif bijaksana. Jika dmufakati ia dibenarkan deh Raja dan diadatkan di dalam neggi dan tduk rantaunya...".

Dalam pasal 3 justru ditegaskan bahwa antara hukum adat dan shara' tidak dipertentangkan Mempunyai hukumdengan adathya, beshhara' Isamdengan agamanya. D an pasal 4 secara tegas menyatakan bahwa ada empat jenis adat yang berlaku, 1) adat yangmenang 2) adat yangdiadatkan 3) adat yang teradat, dan 4) adat istiadat atau disebut tata kram. Kemudian dipertegas pada pasal 12 bahwa: Hidpp dpangku adat, mati dpangku tanah Shara' menaiki adat menumuni.

D ari beberapa pasal yang diuraikan di atas dapat ditarik suatu benang merah bahwa kebijakan hukum yang diterapkan kesultanan adalah hukum adat yang telah dimasuki oleh nilainilai shara.' D engan kata lain bahwa hukum adat yang diterapkan di kesultanan Kutai adalah hukum Islam yang sesungguhnya telah mengalami adaptasi sesuai dengan kebutuhan hukum masyarakat. Di sini letak "keseimbangan hukum" antara hukum Islam dan hukum adat.

Secara politis, dinamika kesultanan Kutai telah mengalami pasang surut. Kondisi ini pun turut memengaruhi kebijakan hukum kesultanan. Panji Selaten dan Beraja Niti semenjak diundangkannya terus diberlakukan secara penuh sampai ditandatanganinya perjanjian pengakuan kekuasaan Gubernemen Hindia Belanda atas kesultanan Kutai oleh Sultan Aji Muhammad Salehuddin pada tanggal 11 O ktober 1844. Selanjutnya, pada tahun 1846 pada masa pemerintahan Sultan Aji Muhammad Sulaiman, Belanda menempatkan Asisten Residen -H. van D ewall-yang berkedudukan di Samarinda. Maka, pemberlakuan kedua undangundang tersebut dibatasi sepanjang tidak bertentangan dengan peraturan perundangan pemerintah Hindia Belanda. ${ }^{8}$

D alam perjalanan selanjutnya, penerapan hukum Islam yang sebelumnya berada di tangan sultan, sejak tahun 1845 atau masa kesultanan berada di bawah D ewan Perwalian

8Pemkab K utai, SalasilahKutai II (Tenggarong: Pemkab Kutai, 1979), 63. 
(1845-1850) telah dibentuk sebuah institusi peradilan sebagai wadah penyelesaian problematika keagamaan masyarakat. institusi ini diberi nama MakkamahAgama (Mahkamah Syari'ah). D an tercatat beberapa nama yang telah memimpin Mahkamah A gama ini, seperti Syekh K haidir (1845-1856), H. Urai Ahmad (1856-1912), Sayyid Muhammad Agil bin Yachya (1912-1918), H. Amin Bone (1918-1926), H. Ali Sono Negoro (1926-1935), Aji Pangeran Ario Cokro Negoro atau Aji Pangeran Ratu (1935-1945), Mohammad Sayyed D aeng Faruku (1945-1948) dan terakhir H. Ahmad Mochsin (1948-1951). ${ }^{9}$

Kewenangan mengadili Mahkamah Agama ini meliputi semua aspek kehidupan masyarakat. D ari persoalan al-ahykal al-shakhsijah—kekeluargaan Islam-sampai persoalan jinayat dan bughat (menentang kekuasaan). Di samping itu Mahkamah Agama ini diberikan kewenangan mengeluarkan izin dakwah para da'i, dan izin mendirikan lembaga pendidikan.

Selanjutnya, formalisasi hukum yang diterapkan oleh kesultanan setidaknya telah menjawab kebutuhan dan rasa kepastian hukum masyarakat Kutai. Ada pemaknaan yang lebih hakiki dari sekedar menformulasikan hukum adat (baca: dalam bahasa hukum formal) menjadi tata aturan hukum bagi sebuah kerajaan, tetapi justru sebaliknya, kesultanan lebih memahami arti sebuah substansi hukum yang diberlakukan.

Bangunan sistem hukum kesultanan yang berpijak di atas hukum adat dengan membagi klasifikasi hukum adat menjadi empat bagian menunjukkan fleksibelitas konstitusi yang diterapkan. Di sini kearifan hukum dibangun tanpa menafikan kearifan-kearifan (hukum) lokal yang telah terlembaga sedemikian rupa. Pasal 4 UU Panji Selaten (konstitusi) menegaskan: Yang dikatakan adat ada empat jenis:

1. Adat yangmemang

2. Adat yang dadakan

3. Adat yang teradat

4. Adat istiadat atau diseat tatakerama

Adat yang memang (baca: lebih bersifat sunatullah) dan adat istiadat merupakan tatakerama yang lazim berlaku dalam kehidupan masyarakat dan lebih menekankan pada aspek budi pekerti (pasal 5 dan 8). A dapun peran institusi kesultanan mengatur tata hukumnya lebih ditekankan pada aspek "adat yang teradat". Hal demikian ditegaskan dalam pasal 6 dan 7 UU Panji Selaten, yaitu:

Pasal 6: Yangdinamakan adat yangdadatkan, yaitu undangyundangnegeri dan kerajaan, tempat mengatur dan menghukumdesa rakyat seta Rajanya. Pasal 7 Yangdimamakan adat yangteradat, yaitu yang belaku pada suatu kaum dan daeah, misalnya adat Modang Bahau, Tunjung Benua', Basap dan sebagainya. Tidak boleh kita mencda adat medka karena sudah terdapat dengan kaumya siapa juapun yang menyalahinya disebut mengyulingkan tata namanya dan dihukum dengan adatrya yang terdapat d daerah itu karena salahnya.

D ari kedua pasal ini hanya adat yangdadatkan yang memungkinkan diadaptasi dengan berbagai sistem nilai termasuk Islam sebagai agama resmi kerajaan.

Meskipun kesultanan Kutai telah menganut Islam sebagai agama resmi kerajaan, namun dalam penerapannya tetap pula diakui hak-hak keyakinan masyarakat atau warga kerajaannya. Dalam hal ini secara institusional hak-hak mereka yang berbeda keyakinan terakomodir dalam lembaga adat yang diadatkan, kecuali ada pengingkaran terhadap sabda Pandta Ratu,

${ }^{9}$ M. Natsir, et.al., Eksistens A gama ISlamdi KabupatenKutai. Laporan Penelitian, Tidak diterbitkan, 2001/ 2002, 40. 
karena pengingkaran demikian sesungguhnya penolakan terhadap wibawa hukum yang dibangun atas kata mfakat dari para orang bijak termasuk ulama, dan sanksinya adalah hukuman mati.

Selanjutnya, peranan shara' (agama Islam) terakomodir secara baik dalam segala bentuk kebijakan hukum kesultanan. Pasal 20 UU Panji Selaten menegaskan:

Kdkuasaan shara' yaitu: "Katakatanya pesan Saidina Muhammad" membei ingat kepada

Raja, mengratkan seggla larangan. Menbenarkan segla sunhan Mengharankan kepada yang haram Menghalalkan kepada yang halal. Ia menata jalan agama. Jad suluh di dalam negri. Mengingat kepada yanglupa. Menbenarkan kepada yangingat. Adat djunjung Guru dia pada yangawnam Sahabat dia pada yang tahu Jadi payung pada fakir miskin Tempat betanya deh negri.

Penerapan konsep siyasah shar'iyah dalam institusi kesultanan dapat dikatakan cukup berimbang. Harasat al-din wa siyasat al-dunyartelah diterapkan sesuai dengan kebutuhan zamannya. Artinya tidak ada peradigma yang paradoksal dalam sistem tata hukum kesultanan. Adat adalah hukum resmi kesultanan, dan adat yang diadakan adalah sangat memungkinkan diakomodir dari ajaran shara'.

Kompetensi yang dimiliki oleh Mahkamah Shar'iyah dengan menerapkan undangundang Beraja Niti meliputi hampir semua aspek kehidupan masyarakat. dari hukuman jinayat (potong tangan) sampai persoalan bughat. Artinya bangunan hukum yang diterapkan di dalam undang-undang ini sedikit banyaknya dipengaruhi oleh pemikiran-pemikiran ulama fiqih di abad pertengahan. Asumsi ini terbangun mengingat peranan ulama di kesultanan Kutai sangat kuat dalam upaya implementasi ajaran Islam, baik dalam struktur pemerintahan maupun dalam bermasyarakat.

Oleh karena itu, penelitian ini dipandang relevan sebagai upaya mengurai konstruksi sistem hukum yang dibangun dalam undang-undang Beraja Niti sebagai undang-undang terapan dari konstitusi kerajaan yaitu undang-undang Panji Selaten. Sehingga akan terlihat peta hukum serta pemikiran hukum yang dominan dalam mempengaruhi sebuah peradaban masyarakat Kutai secara umum.

\section{Sistem Hukum dan Pemetaan Perundangan Kesultanan Kutai Kertanegara}

D alam kajian ilmu hukum, sistem hukum dipahami sebagai suatu kesatuan peraturanperaturan hukum, yang terdiri atas bagian-bagian (hukum) yang memiliki keterkaitan satu sama lainnya dan tersusun sedemikian rupa menurut asas-asasnya, yang berfungsi untuk mencapai suatu tujuan. ${ }^{10}$ Sehingga sistem hukum kesultanan Kutai dengan berbagai subsistem hukum sebagai kesatuan yang bersinergi dengan berbagai pranata hukum yang diberlakukan dalam wilayah kesultanan Kutai, dan hal demikian bertujuan mencapai rasa keadilan hukum masyarakatnya.

Konstitusi kesultanan Kutai pertama kali ditulis pada masa Pangeran Aji Sinum Panji Mendapat (1635-1650), yaitu undang-undang Panji Selaten sebagai konstitusi- (baca: Undang-undang D asar Kesultanan) - dan undang-undang Beraja Niti (Niti) sebagai undangundang terapan. ${ }^{11}$

${ }^{10}$ Riduan Syahrani, RangkumanIntisan IlmuHukum(Bandung: Citra Aditya Bakti, 1999), 169-170. 
Sebagai payung hukum dan konstitusi kerajaan, undang-undang Panji Selaten memang dirancang cukup fleksibel karena hanya memiliki 39 pasal. Sedangkan undang-undang Beraja Niti sebagai undang-undang terapan di Mahkamah Shar'iyah memiliki jumlah pasal yang relatif lebih banyak, yaitu 164 pasal.

Kedua undang-undang ini oleh peneliti dipandang memiliki daya tarik tersendiri. D aya tarik tersebut dapat dilihat dari realitas teoritis eksistensi hukum adat dan hukum Islam yang berlaku di masyarakat, yaitu teori reeqtioin complexu, yang dikemukakan LWC Van D en Berg (1845-1927). D alam kesimpulannya bahwa hukum yang berlaku untuk orang-orang Islam di Indonesia adalah hukum Islam meskipun mengalami beberapa penyimpangan. Hal demikian diperkuat oleh Stbl pemerintah Hindia Belanda tahun 1855 No. 2, pasal 75 RR. ${ }^{12}$

Bantahan terhadap teori Van D en Berg tersebut adalah teori reeqtie, sebuah teori yang menegaskan bahwa hukum yang berlaku bagi masyarakat Indonesia adalah hukum adat, dan hukum Islam dapat berlaku jika telah diresepsi (diterima) oleh hukum adat. Teori ini dikemukakan oleh C. Van Vaollenhoven (1874-1933) dan C. Snouch Hurgronje (19571936)..$^{13}$

Sebuah asumsi yang peneliti kemukakan, bahwa kehadiran kedua undang-undang kesultanan Kutai tersebut setidaknya memberikan penguatan atas teori yang dikemukakan Van D en Berg, yaitu teori receptio in complexu Alasannya adalah bahwa kesultanan telah menjadikan Islam sebagai agama resmi kerajaan, dan mendudukkan hukum shara' sebagai bagian utuh dari sistem hukum yang dibangun.

Pada sisi lain, ternyata legislasi hukum yang dilakukan oleh kesultanan saat itu tetap mendudukkan hukum adat sebagai hukum kerajaan. Sehingga memunculkan "keunikan sistem hukum yang dapat dibaca dalam bunyi pasal 12 undang-undang Panji Selaten, yaitu Hidup d pangkuan adat, mati di pangkuan tamah Shara' menaiki adat menununi. D engan kata lain, keunikan itu terefleksi dari pemahaman yang umum terjadi dalam kajian ilmu hukum, bahwa hukum adat sesungguhnya adalah livinglaw-hukum yang hidup di masyarakat- dan jarang sekali terjadi kodifikasi hukum adat. D an kesultanan Kutai telah melakukan sebuah terobosan hukum untuk menjawab.

\section{Pola Pemetaan Undang-Undang Beraja Niti}

Undang-undang Beraja Niti memiliki sekitar 163 pasal yang mengatur tentang kenegaraan, mu'amalah, jinałah, kewarisan, peradilan, perbudakan, kelautan, zakat, ketentuan hewan piaraan, etika, pernikahan, dukun dan peramal, sumpah, pelacuran, pemeliharaan anak.

Sebagai contoh, dalam persoalan kenegaraan yang mencakup 27 pasal- (pasal 1, 2, 3,

\footnotetext{
${ }^{11}$ TIM Peneliti STAIN, "Sejarah Perkembangan Hukum Islam di K alimantan Timur," Laporan Penelitian, 2003/ 2004, STAIN Samarinda, 25.

${ }^{12}$ Ada beberapa pakar yang mempunyai kesimpulan yang sama, yaitu Carel Frederik Winter (1799-1859) dan Salomon Keyzer (1923-1868). Lihat, Ismail Suny, HukumIdamdalamHukumNasional(Jakarta: UMJ Press, 1987), 5-6. bacajuga, Sayuthi Thalib, Reeqtioa Contranio HubunganHukumA datdangan HukumIdam(Jakarta: Academika, 1980), 7.

${ }^{13}$ Hukum Islam dapat berlaku apabila telah memenuhi dua syarat, petama, noma hukum Islam harus diterima terlebih dahulu oleh hukum adat masyarakat setempat. Keedua, kalaupun sudah diterima oleh hukum adat, norma dan kaidah hukum Islam tersebutjuga tidak boleh bertentangan maupun tidak boleh telah diatur lain oleh ketentuan perundang-undangan Hindia Belanda. Baca, Idris Ramulyo, Asasasas HukumIsam SgarahTimbul danBekkerbangya Kedudukan HukumIdamdalamSistemHukumd Indonesia (Jakarta: Sinar G rafika, 1977, 56-57. lihat juga Amrullah Ahmad, et.al., Dimens HukumIdamdalamSistenHukumNasional (Jakarta: G ema Insani Press, 1996), 212.
} 
$4,5,6,7,22,34,48,49,53,54,57,63,64,108,119,111,112,113,114,118,122,126$, $129,130)$, membicarakan tentang prinsip-prinsip dalam menjalankan pemerintahan, seperti Raja harus memiliki sifat keadilan, musyawarah, mufakat, arif, bijaksana, peduli, pemaaf, tegas, selektif, penyayang, pengayom, santun, dermawan, pemberani, toleransi dan jujur.

Kebijakan Raja terhadap rakyat yang mempunyai kelebihan dalam pengobatan dan mengetahui hal yang gaib bagi mereka diayomi dan diberdayakan oleh kerajaan. Kebijakan Raja tentang mengayomi rakyat yang terlantar, yang terganggu jiwa atau ekonomi lemah, termasuk anak dan isteri yang suaminya terbunuh ketika membela kerajaan, sehingga terhadap anak dan isteri yang terbunuh disebabkan menentang raja (makar) dengan memberikan sanksi bagi mereka yang makar berupa dipenggal lehernya dan digantung di alun-alun untuk dipertontonkan kepada rakyat, rumahnya dibakar dan hartanya dirampas. Tetapi Raja juga dapat memberikan amnesti terhadap rakyat yang menyerah.

Kebijakan raja juga berkaitan bagi mereka yang menentang titah Raja maka harus dibunuh. Kebijakan bagi mereka yang diundang secara khusus oleh kerajaan harus memakai pakaian berwarna kuning. Kebijakan bagi Raja untuk menikah dengan yang seimbang derajat dan martabatnya. Kebijakan yang merupakan hak Raja terhadap orang yang terusir.

Dalam persoalan pidana ada sekitar 47 pasal, yaitu pasal-pasal tentang pidana pembunuhan, pencurian, perampokan, penganiayaan, penculikan, pencabulan, mengganggu rumah tangga raja, membawa senjata tajam, perjudian, penadahan, hukuman berupa denda, menyogok, perzinahan, penghasut, pemaafan pidana, penjaminan tersangka, penyuruh pidana.

Bentuk ketentuan umum penerapan hukum pidana dalam sistem hukum kesultanan Kutai yaitu bahwa tidak diperkenakan menghakimi hamba yang bersalah bila menghakimi maka raja harus menjatuhkan hukuman yang sesuai dengan kesalahannya (pasal 52). Pasal 52 tersebut merupakan refleksi dari asas legalitas ${ }^{14}$ bahwa setiap tindak pidana dinyatakan bersalah setelah melalui proses peradilan dan terbukti kesalahan yang telah dilakukan. Artinya dalam penjatuhan sanksi harus dapat dibuktikan secara hukum, yakni seseorang akan menerima sanksi hukuman melalui proses hukum dengan mengindahkan delik pasal yang dilanggar. Sebagaimana bunyi wahyu Allah dalam al-Q ur'an surah Bani Israil ayat 15 dan alQ ashas ayat 59 sebagai landasan eksistensi asas legalitas dalam hukum shara'.

D alam pelanggaran pidana juga dikenal beberapa jenis sanksi seperti sanksi pembunuhan, sanksi potong tangan (pasal 119 dan 120), sanksi penyitaan. Sanksi denda yang terdapat pada beberapa pasang undang-undang Beraja Niti; buruh bila mati maka tidak kena denda yang punya pekerjaan (pasal 139), apabila menyuruh orang untuk mengerjakan sesuatu bila terjadi kecelakaan maka ia harus membiayai seluruh biaya kematian (pasal 143), pembayaran sanksi denda harus ada sanksi (pasal 26). Beberapa ketentuan sanksi tersebut tampak memiliki kesamaan dengan ketentuan yang ada dalam al-Qur'aß.

Bahkan, ditemukan beberapa pasal yang memiliki semangat sama dengan prinsip muqas)d al-shari'ah, "Menutup mafsadat atau kerusakan itu lebih utama daripada menarik kemasalahatan". Di antara pasal itu adalah tentang sanksi pencurian senjata. Menurut

${ }^{14}$ Dalam sistem hukum pidana Indonesia, azas legalitas dimaknai sebagai sesuatu peristiwa pidana tidak dapat dikenai sanksi jika tidak ditemukan ketentuan yang mengaturnya, atau disebut juga nullumddicumnulla poenasine praaialegepoenali. Bachsan Musthafa, SistemHukumIndonesia (Bandung: Remaja Karya, 1984), 71. 
ketentuan ini pencuri senjata dibunuh dan orang yang menyimpannya didenda (pasal 36). Hal ini didasarkan kepada pertimbangan bahwa orang yang melakukan pencurian terhadap senjata dapat membuka peluang untuk terjadi tindak pidana pembunuhan yang dapat menghilangkan nyawa orang lain.

Meski begitu, ditemukan juga beberapa ketentuan yang diduga kuat bersumber pada hukum adat setempat, seperti kasus "salah tangkap". Pencuri yang tertangkap dapat bebas. Bagi masa yang menghakimi pencuri (salah tangkap) tidak dikenakan sanksi. D alam pasalpasal tersebut terlihat ada perpaduan yang sangat substansial antara hukum adat dengan hukum Islam.

Lebih lanjut, dapat dikemukakan contoh ketentuan undang-undang Beraja Niti yang lain seperti masalah mu'amalah (perdata). Terdapat sekitar 38 pasal yang terkait erat dengan persoalan hukum mu'amalah, seperti jual beli, hutang piutang, pinjam meminjam, kewarisan dan lain-lain.

D alam hal utang piutang, undang-undang Beraja Niti mengatur dalam beberapa pasal, seperti sanksi bagi orang yang melanggar tata aturan dalam penyelesaian utang piutang tersebut.

Ketentuan sanksi dalam utang piutang yang berlaku secara adat istiadat di kesultanan Kertanegara merupakan penegasan dari kebiasaan yang berlaku di masyarakat agar dihargai dan dijunjung tinggi serta tidak berlaku semena-mena baik kepada kedua belah pihak yang bertransaksi.

Hutang tidak boleh berbunga (pasal 44), hutang ditanggung suami saja jika tanpa sepengetahuan anak dan istri (pasal 45), istri menanggung hutang suami, jika ditagih gugur hukumnya sebagai sanksi (pasal 47), bagi orang yang berpiutang tidak boleh merampas dan membungakan. Jika dilakukan, maka akan dikenakan didenda (pasal 123), orang yang berhutang dan tidak mau membayar, maka dilaporkan kepada pembesar negeri, dan hutangnya harus dibayar (pasal 125), orang yang berhutang jika bekerja pada pemberi hutang maka jika makan tidak harus dibayar jika tidak makan, hutangnya dikurangi (pasal 133), bagi orang yang bekerja jika diberi makan maka tidak dihitungkan sebagai hutang (pasal 134), penagih hutang jika terjadi kecelakaan maka harus disantuni oleh orang yang menyuruh (pasal 138), keharusan adanya alat bukti tertulis dalam utang piutang, tukang tagih harus membawa 2 atau 3 orang sebagai saksi dan membawa alat bukti, sehingga dapat dibayar (pasal 65), jika hamba merdeka dan punya hutang maka wajib membayar hutang dari harta yang dimilikinya (pasal 83).

Sebagaimana dalam persoalan pidana, dalam mu'amalahpun ditemukan beberapa ketentuan yang sama dengan hukum Islam, seperti larangan bunga, keharusan mengambil hutang dan perlunya "akad" transaksi.

D alam bidang jual beli, undang-undang Beraja Niti mengatur tentang etika jual beli, persyaratan penjual dan pembeli yang harus dipenuhi karena menyangkut sah tidaknya transaksi jual beli, persyaratan barang yang diperjualbelikan, mekanisme jual beli, tidak adanya kesepakatan para pihak.

Tidak dibenarkan menjual barang atau hamba tanpa izin yang punya. Jika terjual maka harus ditebus dan kembalikan kepada yang punya (pasal 69), tidak sah jual beli oleh orang yang belum baligh dan oleh anak-anak (pasal 70), tidak sah jual beli minuman keras, anjing, 
babi (pasal 71), tidak salah jual beli anjing pemburu dan gajah (pasal 72), jual beli harus dengan barang berwujud (pasal 73), tidak sah jual beli hamba temuan (pasal 74), hamba yang minta tolong dijualkan barangnya jika tidak sesuai harganya maka harus diganti (pasal 75), kelebihan dari harga yang ditentukan tidak boleh diambil karena hamba dan hartanya merupakan milik tuannya (pasal 76), tidak salah jual beli dengan hamba (pasal 77), wajib mengembalikan barang yang tertinggal dari rumah yang dijual (pasal 78), jual tanah yang ada tanamannya makam menjadi hak pembeli kecuali ada perjanjian atas padi yang siap panen (pasal 79).

Barang yang sudah terjual tidak dapat dikembalikan (pasal 80), barang perniagaan yang dititipkan kepada pedagang maka jika ingin mengambil harganya harus sepengetahuan hakim (pasal 84), dalam hal jual beli dan pinjam meminjam harus ridha sama ridha (pasal 141). $\mathrm{D}$ an jenis barang yang dijual-belikan termasuk di dalamnya adalah hamba dan ada beberapa pasal yang mengatur tentang transaksi hamba tersebut, yaitu hamba yang suka melarikan diri, pencuri, gila berpenyakit tidak wajib dikembalikan kepada pembeli (pasal 81), dalam pembelian hamba harus diperiksa budi perangainya, mental dan fisiknya, yang memeriksa harus sejenis (pasal 101).

D ari beberapa contoh pasal-pasal dalam undang-undang Beraja Niti di atas, di samping hukum adat, ditemukan banyak ketentuan yang sama persis dengan ketentuan hukum Islam (fiqih). Oleh karena itu, kiranya tidak berlebihan jika dikatakan bahwa di kerajaan Kutai berlaku hukum Islam. Karena, materi hukum yang diterapkan merujuk kepada hukum-hukum yang ada dalam hukum Islam. A palagi jika dicermati, penerapan hukum adat dalam undangundang Beraja Niti, secara substansial tidak bertentangan dengan hukum Islam.

\section{Penutup}

Dengan mencermati substansi undang-undang Beraja Niti, dapat dikatakan bahwa bentuk kebijakan hukum yang diterapkan oleh Kesultanan Kutai Kertanegara adalah hukum Islam yang merespon dan mengakomodir realitas hukum masyarakat adat- shara' memiiki, adat menunui. Keberadaan undang-undang Beraja Niti sebagai produk undang-undang yang bersifat terapan pada dasarnya memiliki kompleksitas sistem hukum terapan yang diformulasikan menjadi sebuah undang-undang. Karena, di samping memuat hukum adat, juga mengadopsi hukum Islam mulai dari persoalan perdata sampai dengan pidana.

\section{Daftar Rujukan}

Amrullah Ahmad, et.al., Dimensi HukumIdamdalamSistemHukumNasianal, Jakarta: G ema Insani Press, 1996, 212.

Bachsan Musthafa, SistemHukumIndonesia, Bandung: Remaja Karya, 1984.

Idris Ramulyo, Asasasas HukumIsam Sejarah Timbul dan Bekenbangya Keedudukan Hukum Islam dalam Sistem Hukumdi Indonesia, Jakarta: Sinar G rafika, 1977.

Ismail Suny, HukumIdam dalamHukumNasianal, Jakarta: UMJ Press, 1987.

M. Natsir, et.al., "Eksistensi Agama Islam di Kabupaten Kutai", Laporan Penelitian, Tidak diterbitkan, 2001/ 2002.

Muhammadunnasir, Syed, Isam Its Coneqds \& Histary. New D elhi: Kitab Bhavan, 1981. 
Murjani et.al, Pekenbangan Penerapan HukumIdamdi Kalimantan Timur. Samarinda: STAIN Samarinda, 2004.

Murjani, Pekenbangan Legislasi Hukum Isam dalam Penbentukan Sistem Hukum Nasional: Tinjauan Yunidis Pditis Tesis, Magister (S-2) Ilmu Hukum, UII Yogyakarta, 2002.

Pemkab Kutai, Salasilah Kutai II. Tenggarong: Pembkab Kutai, 1979.

Riduan Syahrani, Rangkuman Intisan Ilmu Hukum Bandung: Citra Aditya Bakti, 1999.

Sayuthi Thalib, Reeqtio a Contranio, Hubungan Hukum Adat dengan Hukum Islam Jakarta: Academika, 1980.

Setwilda TK II Kutai, G elora, MahakamdalamCuplikan Tulisan Tenggarong: Setwlda, 1999. as-Suyuti, Jalaluddin Abdurrahman bin Abi Bakar, Tarikhal-Khulafa Beirut: D ar al-Ilm li alMalayin, 1974.

D epdikbud Kaltim, Wujud, Arti dan Fungsi Puncak-Puncak Keaudayaan Lama dan Asi di Kalimantan Timur. Kaltim D epdikbud, 1996.

Tim Peneliti STAI, SgarahPekkenbanganHukumIsamdi KalimantanTimr, laporan Penelitian, 2003/ 2004, STAIN Samarinda. 